Abstracta Iranica Abstracta Iranica

Revue bibliographique pour le domaine irano-aryen

Volume 40-41 | 2019

Comptes rendus des publications de 2017-2018

\title{
Stefan Heidemann, Kevin Butcher. Regional History and the Coin Finds from Assur. From the Achaemenids to the Nineteenth Century
}

\section{Astrid Nunn}

\author{
(2) OpenEdition \\ Journals \\ Édition électronique \\ URL : http://journals.openedition.org/abstractairanica/47749 \\ DOI : 10.4000/abstractairanica.47749 \\ ISBN : 1961-960X \\ ISSN : 1961-960X \\ Éditeur : \\ CNRS (UMR 7528 Mondes iraniens et indiens), Éditions de l'IFRI
}

\section{Référence électronique}

Astrid Nunn, «Stefan Heidemann, Kevin Butcher. Regional History and the Coin Finds from Assur. From the Achaemenids to the Nineteenth Century 》, Abstracta Iranica [En ligne], Volume 40-41 | 2019, document 3, mis en ligne le 15 juillet 2019, consulté le 23 avril 2021. URL : http://

journals.openedition.org/abstractairanica/47749; DOI : https://doi.org/10.4000/abstractairanica 47749

Ce document a été généré automatiquement le 23 avril 2021.

Tous droits réservés 
Stefan Heidemann, Kevin Butcher. Regional History and the Coin Finds from Assur. From the Achaemenids to the Nineteenth Century

Astrid Nunn 


\section{RÉFÉRENCE}

Stefan Heidemann, Kevin Butcher. Regional History and the Coin Finds from Assur. From the Achaemenids to the Nineteenth Century. Wiesbaden : Harrassowitz Verlag, 2017, p. XIV+ 128, $31 \mathrm{pl}$, (Wissenschaftliche Veröffentlichungen der Deutschen Orient-Gesellschaft 148)

D'après les carnets de fouilles environ 1000 pièces de monnaies et 19 trésors ont été découverts entre 1903 et 1914 à Assur. Il semble que la plus grande partie se trouve au Vorderasiatisches Museum de Berlin, mais le Musée d'antiquités orientales d'Istanbul (Eski şark Müzesi) en conserve certainement aussi. La publication de cette collection a été répartie entre deux numismates. Kevin Butcher a examiné les monnaies les plus anciennes et Stefan Heidemann les plus récentes.

2 Le chapitre sur les monnaies les plus anciennes rassemble 450 pièces conservées à Berlin et 72 connues par des photos anciennes. Celles-ci sont achéménide (une), séleucides et arsacides/hellénistiques (no. 2-98), romaines provinciales (no. 99-221), parthes (no. 222-405) et romaines impériales (no. 406-418). La plus ancienne et à la fois la seule monnaie achéménide est un sheqel d'environ 400 av. J.-C.

La seconde partie rassemble environ 300 monnaies de l'époque sassanide au XIXème $s$. De cette partie les plus anciennes sont trois monnaies sassanides, dont une remonte à Ardeshir I (240/241 av. J.-C.) et une à Shapour II.

\section{AUTEURS}

\section{ASTRID NUNN}

Université de Munich 